\title{
sciendo
}

Research Article

(C) 2019 Irisi Kasapi and Ines Nurja. This is an open access article licensed under the Creative Commons Attribution-NonCommercial-NoDerivs License (http://creativecommons.org/licenses/by-nc-nd/3.0/).

\section{The Influence of Cognitive Image on Tourist Loyalty: A Study of Foreign Tourists Visiting Tirana City}

\author{
Irisi Kasapi \\ Lecturer of Marketing, \\ Department of Business and Economics, \\ University of New York Tirana \\ Ines Nurja \\ Assistant Professor of Statistics and Econometrics, \\ Department of Finance and Economics, \\ University of New York Tirana
}

Doi: $10.2478 / \mathrm{mjss}-2019-0006$

\begin{abstract}
This paper attempts to shed light on the concepts of cognitive and affective image and investigate the effects of destination image on tourist loyalty, though one of the aforementioned aspects of destination image. Data was collected using the convenience sampling method. After a review of the most crucial places where foreign visitors could turn into during their stay in Tirana, there were identified a few attractive interception points. Structural Equation Modelling (SEM) was used to test the hypotheses constructed. SPSS 20.0 statistical package was employed in this particular study for the descriptive analysis of the sample, while LISREL 9.30 was used for structural equation modelling. The results of the study showed that cognitive image had a direct and significant influence on affective image, explaining in this way the formation process of the destination image concept. Moreover, when examining the relationship between destination image and tourist loyalty it was found out that cognitive image had a direct influence on tourist loyalty. The results of the study prove to be beneficial both at an empirical and practical level. As a matter of fact, it does not only provide insightful information for tourism operators and policy-makers, but it also contributes in the body of knowledge of the country where the study takes place.
\end{abstract}

Keywords: Destination Image, Tourist Loyalty, Foreign Tourists, Tirana, Albania

\section{Introduction}

Tourism is considered to be a very important sector of the economy in Albania. With the increased presence of foreign tourists in the country, it is observed that a substantial number of foreign visitors is entering Tirana, as well. Tirana, the capital of Albania since 1920, and the largest city of the country, has a population of 883,996 inhabitants (as of January 1st, 2018; INSTAT, 2018). The city is host to many public institutions and public and private universities, and is the center of the political, economic, and cultural life of the country. If we look through the historical lenses of Albania in general we would observe that between 1945 up to the beginning of the 90s' the country has experienced one of the harshest authoritarian regimes; the economy was centralized and the inward flow of foreign tourists was prohibited by the regime. As Aliaj describes the situation,

"Indeed it was considered a strict 'no fly zone' for tourists and any international transportation mean, both from east and west. The rest of the world was considered by the authoritarian regime of 
that time as "degenerate and corrupt'!" (Aliaj, 2015, p. 9). The path from communist era until these days has made of Albania an appealing case of a newly emerging destination in the international tourist market, which in turn has led to the country being ranked as one of the top destinations recommended for 2011. Despite the increase in the flow of foreign tourists, there exists little or no research that investigates the perceptions of foreign tourists visiting Albania in general and those related to Tirana. Accordingly, this study aims at investigating the influence of destination image on tourist loyalty of foreign visitors visiting Tirana city. The results of this study can provide beneficial insights to policy-makers and tourism operators in the country, so as to better position the city in the international tourist market.

\section{Literature Review}

\subsection{Destination Image}

Studies conducted on destination image are quite abundant. As such, to only name a few there are Gartner and Levy, (1955), Levy, (1959), Dobni and Zinkhan, (1990), Keller, (1993), Aaker, (1996), de Chernatony \& Dall'Olmo, (1998). Whereas Gartner and Levy (1955) were the first to propose a definition of 'brand image', the first inquiry investigating destination brand image started in the early 70's with the studies proposed by Gunn (1972) and Hunt (1975). As Milman and Pizam define in their work 'The Role of Awareness and Familiarity with a Destination: The Central Florida Case',

"Destination image may be referred to as the visual or mental impression of a place, a product, or an experience held by the general public. In order to capture certain market segments, suppliers of the tourist product attempt to develop a favorable image of their destination or product in order to stimulate demand to visit those places" (1995:21).

In continuation of the above idea brought forth through the definition, Cai (2009) further argues that the intangibility and impossibility of consumption of the tourism products demonstrate that only destinations that are positively positioned in terms of image are more prone of being chosen by potential tourists (2009: 1). According to this author, image should not be investigated only before the visit, but also after the visit "as it serves as the criterion against which the tourist's initial perception and actual experience are compared, and thereupon determines tourist satisfaction, repeat visit intention and word-of-mouth communication" (2009: 1). Similarly, other scholars acknowledge the importance of studying 'image' because of the important role it plays in tourists' destination overall behavior (Echtner and Ritchie 1993; Gallarza et al 2002; Hunt 1975).

\subsection{Tourist Loyalty}

The research on brand loyalty and consumer loyalty dates back more than forty years ago. Nevertheless, the exploration of the 'loyalty' dimension based on the wider area of tourism, hospitality and recreation and leisure is quite recent, dating back only ten years ago (Opperman, 2000, p. 79). According to Opperman, one among very few authors who have contributed in exploring tourism brand loyalty, notes, "Destination loyalty essentially places the emphasis on a longitudinal perspective, looking at lifelong visitation behaviour of travellers rather than just at a cross-sectional perspective in which today's visitation is completely unrelated to previous visitation or, in a more general perspective, to previous experience per se" (2000:80). For that matter, measuring tourist loyalty is a crucial aspect for destination marketers, as loyal customers represent the bundle of 'returning' and 'recommending to others' type of customers.

Further, Oliver (1999, p.34) defines tourist loyalty as "a deeply held commitment to rebuy or repatronize a preferred product/service consistently in the future, thereby causing repetitive samebrand or same brand-set purchasing, despite situational influences and marketing efforts having the potential to cause switching behavior". 


\subsection{Hypotheses development}

Various studies have been showing a strong relationship between the two components of 'destination image', pointing out that the cognitive constituent is foregoer of an affective evaluation (Baloglu, 2000; Baloglu and McCleary, 1999; Gartner, 1994). Further, research suggests that destination image is a predictor of tourist loyalty (Cai et al., 2003; Chen and Tsai, 2007; Tasci and Gartner, 2007). In light of the above short discussion; the following hypotheses are proposed to be tested:

H1. Cognitive Image will significantly influence Affective Image

H2. Cognitive Image will significantly influence Tourist Loyalty.

\section{Methodology}

\subsection{Data collection and Operationalization of the variables}

Data collection was realized using the convenience sampling method. Foreign visitors, new and repeat, non-business and business ones, from various interception points encompass the main target group. The Tirana Tourist Information Point located at 'Mother Tereza' International Airport; the Tourist Information Center located at the heart of Tirana city; right behind the National Museum; various souvenir shops, located in the city and at the Airport as well; main cultural, historical, and natural attractions, more specifically the National Museum, the Dajti Mountain, etc., were used as the main interception points. Data was collected over a period of 1 year, from May 2016 until June 2017. After excluding invalid surveys, a total of 385 completed questionnaires were taken into consideration for further analysis.

Table I summarizes the respondents' profile. It is observed that most of the research participants were female $(n=166,43.1 \%$. It is interesting to notice that most of the respondents are aged over 56 years old $(n=140,36.4 \%)$. A great majority of the respondents were travelling for the first time $(n=329,85.5 \%)$ to Tirana city.

Table 1. Demographic characteristics of respondents

\begin{tabular}{|c|c|c|}
\hline Characteristics & Frequency & Percentage (\%) \\
\hline \multicolumn{3}{|l|}{ Gender } \\
\hline Male & 128 & 33.2 \\
\hline Female & 166 & 43.1 \\
\hline Missing & 91 & 23,6 \\
\hline \multicolumn{3}{|l|}{ Age (years) } \\
\hline $16-25$ & 38 & 9.9 \\
\hline $26-35$ & 41 & 10.6 \\
\hline $36-45$ & 50 & 13.0 \\
\hline $46-55$ & 116 & 30.1 \\
\hline$>56$ & 140 & 36.4 \\
\hline \multicolumn{3}{|l|}{ Past experience } \\
\hline Repeated visitor & 56 & 14.5 \\
\hline First-time visitor & 329 & 85.5 \\
\hline \multicolumn{3}{|l|}{ Income } \\
\hline Choose not to answer & 60 & 15.6 \\
\hline Less than $\$ 9,999$ & 15 & 3.9 \\
\hline$\$ 10,000-14,000$ & 12 & 3.1 \\
\hline$\$ 15,000-24,999$ & 8 & 2.1 \\
\hline$\$ 25,000-34,999$ & 16 & 4.2 \\
\hline$\$ 35,000-49,999$ & 26 & 6.8 \\
\hline$\$ 50,000-74,999$ & 40 & 10.4 \\
\hline$\$ 75,000-99,999$ & 44 & 11.4 \\
\hline$\$ 100,000-149,999$ & 19 & 4.9 \\
\hline$\$ 150,000-199,999$ & 21 & 5.5 \\
\hline$\$ 200,000$ and above & 9 & 2.3 \\
\hline Missing & 115 & 29,9 \\
\hline
\end{tabular}


When it comes to the issue of measurements, scale development and operationalization was based on previous research findings, followed by a purification of the items with the purpose of testing the scale in order to use it in the context of Tirana city. As such, because the scale of 'destination image' was previously validated in other studies, six items were extracted from the literature review to measure cognitive image (Konecnik, 2010) and three items for affective image (Pike and Ryan, 2004). Items were evaluated using a five-point likert scale ranging from 1 (strongly disagree) to 5 (strongly agree).

\subsection{Data Analysis}

Data analysis was carried out in three stages. First, SPSS 20.0 statistical package was used to perform the descriptive analysis of the sample group. Second, confirmatory factor analysis (CFA) was used to measure the reliability and validity of the observed and latent variables. Third, Diagonally Weighted Least Squares was evaluated in the structural equation modeling (SEM), for which LISREL 9.30 was used as a tool to carry out the analysis and test the hypothesis.

\section{Findings}

\subsection{Reliability and validity measurement}

Reliability and validity are evaluated in this study, as well. Cronbach's $\alpha$ and Composite Reliability $(\mathrm{CR})$ were investigated in order to evaluate the reliability of the measurement items. As described in Table 2, the values of Cronbach's a exceeded the recommended level of 0.70 suggested by Nunnally (1978). Alike Cronbach's $\alpha$, the CR values ranged from 0.798 to 0.893 exceeding again the threshold proposed in the literature by Fornell \& Larcker (1981). Further, an attempt was made to examine the validity issue by considering convergent validity. As shown in Table 2, two of the constructs exhibit factor loadings and average variance extracted (AVE) higher than 0.50 , which is the acceptable level suggested by Hair et al., (2010). The other construct on the other hand needs further improvement, as at this stage it shows an AVE value of 0.477.

Table 2. Reliability and Validity measures

\begin{tabular}{lccc} 
Measured items & Standardized loadings & CR & AVE \\
\hline Cognitive Image $(\boldsymbol{\alpha}=\mathbf{0 , 8 0 6 )}$ & & 0,828 & 0,447 \\
Nature & 0,61 & & \\
Resorts \& Hotels & 0,61 & & \\
Recreational activities & 0,72 & & \\
Good shopping facilities & 0,66 & & \\
Nightlife and Entertainment & 0,74 & & \\
Interesting Historical attractions & 0,66 & & \\
Affective Image( $\boldsymbol{\alpha}=\mathbf{0 , 7 5 0 )}$ & & & \\
Exciting & 0,64 & & \\
Pleasant & 0,89 & & \\
Relaxing & 0,72 & & \\
Tourist Loyalty ( $\boldsymbol{\alpha}=\mathbf{0 , 8 3 6})$ & & &
\end{tabular}

\subsection{Hypothesis testing}

According to the SEM results, the conceptual model at this stage revealed an adequate level of model fit, with $\times 2(40)=96.49, \times 2 / d f=2.41$, SRMR=0.065, TLI=0.957, CFI=0.969, GFI=0.988 $(\mathrm{Hu}$ and Bentler, 1999). As noted in Figure 1, the path from 'Cognitive Image' to 'Affective Image' is significant; therefore, $\mathrm{H} 1$ is supported. Further, the path from 'Cognitive Image' to 'Tourist Loyalty' is also significant; therefore $\mathrm{H} 2$ is supported. 


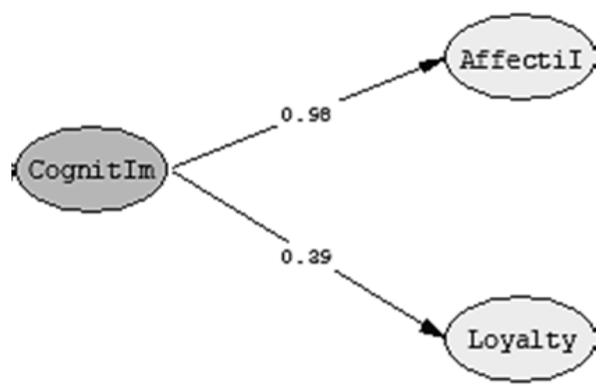

Figure 1. Conceptual model

\section{Discussion}

With the emergence of the country as a preferred destination in the international tourist market, it is of vital importance to understand the foreign tourist's destination choices and their perceptions during their trips in the country, and more specifically to Tirana city, which is the scope of this research. According to the results of this research, the following observations can be drawn.

First, our research revealed that in the formation process of the destination image concept both the cognitive and affective element play a great role in creating someone's image regarding a destination.

Second, according to our findings, cognitive image with factors such as nature, resorts, shopping facilities, play an important part in explaining tourist loyalty.

\subsection{Limitations and future research}

Although in part this study is a fresh contribution in the Albanian marketing literature, it still has its limitations. One of them is the fact that due to the lack of accurate data related to foreign tourists visiting Tirana only, we have used a convenience sampling method. Further, we accounted as valid research participants even those tourists whose first destination choice was not Tirana. Future research might encompass testing any brand equity models with the purpose of branding Tirana city from a customer-based perspective.

\section{References}

Aaker, D. A. (1996). Building Strong Brands. New York: Free Press.

Aliaj, B. (2015). Albania: the role of design, planning, and landscaping for the National growth, image building, and branding. Published in DURANA: A project of the Joint International PhD Program Polis University - Ferrarra University, Italy. Retrieved November 9, 2015 from http://issuu.com/universiteti_polis/docs/libri_phd_web_ok.

Baloglu, S. (2000), "A path model of visitation intention involving information sources, socio-psychological motivations, and destination image" Journal of Travel and Tourism Marketing, Vol.8, No.3, pp. 81-90.

Baloglu, S. and McCleary, K.W. (1999), "A model of destination image formation", Annals of Tourism Research, Vol.26, No.4, pp.868-897.

Cai, L. A. (2009). "Brand Knowledge, Trust and Loyalty - A Conceptual Model of Destination Branding" International CHRIE Conference-Refereed Track. Paper 12.http://scholarworks.umass.edu/refereed/Sessions/Friday/12.

Cai, L.A., Wu, B.T. and Blai, B. (2003). "Destination Image and Loyalty", Tourism Review International, Vo. 7, No.3/4, pp.153-162.

Chen, C.F. and Tsai, D. (2007), "How destination image and evaluative factors affect behavioral intentions?" Tourism Management, Vol.28, No. 4, pp. 1115-1122.

De Chernatony, L. and Dall'Omo Riley, F. D. 1998. Defining "brand" beyond the literature with experts' interpretations. Journal of Marketing Management, 14: 417-443.

Dobni, D. and Zinkhan, G. M. 1990. "In search of brand image: A foundation analysis", Advances in Consumer Research, 17: 110-119. 
Echtner, C., and B. Ritchie. (1993). "The Measurement of Destination Image: An Empirical Assessment", Journal of Travel Research, Vol. 31, No.4, pp.3-13.

Fornell, C. and Larcer, D.F. (1981), "Evaluating structural equation models with unobservable variables and measurement errors", Journal of Marketing Research, Vol.18, No.1, pp.39-50.

Gartner, B.B. and Levy, S.J. (1955). "The product and the brand", Harvard Business Review, March-April, pp. 33-9.

Gallarza, M., S. Gil, and G. Calderon. (2002). "Destination Image: Towards a Conceptual Framework", Annals of Tourism Research , Vol. 29:, pp.56-78.

Gartner, W.C. (1994), "Image formation process", Journal of Travel \& Tourism Marketing, Vol. 2, no.2/3, pp.191216.

Gunn, C.A. (1972). Vacationsecape: Designing Tourist Regions, Taylor \& Francis, Washington.

Hunt, J. (1975). "Image as a Factor in Tourism Development", Journal of Travel Research, Vol.13, No.4, pp.1-7.

Hair, J.F., Black, W.C., Babin, B.J., and Anderson, R.E. (2010), Multivariate Data Analysis, $7^{\text {th }}$ ed., Prentice-Hall, Englewood Cliffs, NJ.

Hu, L.T. and Bentler, P.M. (1999), "Cutoff criteria for fit indexes in covariance structural analysis: conventional criteria versus new alternatives", Structural Equation Modeling: A Multidisciplinary Journal, Vol. 6, No.1, pp.1-55.

Hunt, J.D. (1975). "Image as a Factor in Tourism Development", Journal of Travel Research, Vol 13, Issue 3, pp. $1-7$.

Keller, K. L. 1993. Conceptualizing measuring and managing consumer-based brand equity, Journal of Marketing, 57: 1-22.

Konecnik, M. (2010). "Extending the Tourism Destination Image Concept Into Customer-Based Brand Equity for A Tourism Destination", Ekonomska istraživanja, Vol. 23(3),24-42.

Levy, S. J. 1959. Symbols for sales. Harvard Business Review, 37(4): 117-124.

Nunnally, J.C. (1978), Psychometric Theory, $2^{\text {nd }}$ ed., McGraw-Hill, New York, NY.

Oppermann M (2000), "Tourism Destination Loyalty", Journal of Travel Research, Vol. 39, pp. 78-84.

Oliver,R.L., "Whence consumer loyalty?", Journal of Marketing, vol. 63, pp. 33-44, Special Issue 1999.

Pike, S. and Ryan, C. (2004), "Destination positioning analysis through a comparison of cognitive, affective, and conative perceptions", Journal of Travel Research, Vol. 42, No.4, pp.333-342.

Tasci, A.D. and Gartner, W.C. (2007), "Destination Image and its functional relationships", Journal of Travel Research, Vol.45, No.4, pp.413-425. 